\section{Capacity Building}

Veronica Junjan

Department of Public Administration, University of Twente, Enschede, The Netherlands

\section{Synonyms}

Administrative reforms; Organization development; Public administration reform

\section{Definition}

Capacity building refers to a broad palette of techniques and methods that help individuals, organizations, and communities develop solutions to address the obstacles which prevent them in reaching their development goals.

\section{Introduction}

This entry provides first an overview of the main characteristics of the concept and a short historical overview. Subsequent sections present profiles for the different approaches developed over time, with particular focus on administrative capacity building. A separate section discusses the relationship between the concept of "capacity building" and of "capability approach."

\section{Concept Characteristics and Historical Evolution}

Present in the policy discourse and in the scientific studies during the 1960s as a component of administration development (Pollitt and Bouckaert 2011), the concept of "capacity development" was initially coupled to the reconstruction efforts focused on development public administration in the newly set-up states. The concept started to be used more intensely during the 1970s, primarily by the United Nations Development Programme. At the time, its primary meaning referred to the provision of assistance for "institution building". The activities included under this term were focused on designing organizations able to provide different types of public services to the citizen, and on developing human resources able to provide the new types of services needed at societal level.

Capacity building (re)emerged in the 1990s as a consequence of the efforts undertaken internationally towards major societal reconstruction realized to a large extent in developing countries. These actions were concentrated in the beginning in the area of international development. This approach became central to the activities undertaken both by major international organizations carrying out activities in the area of international development (World Bank WB, United Nations UN, United Nations Development Programme UNDP, European Commission EC/EU, Organization for Economic Cooperation Development 
OECD). National based public and non-profit organizations, such as Canadian International Development Agency CIDA, Deutsche Gesellschaft für Internationale Zusammenarbeit $\mathrm{GmbH}$ (GIZ GmbH Germany), or Swedish International Development Agency (Sweden) played prominent roles in providing capacity assistance programs to different countries.

The variety of the organizations used and defined the concept according to their own goals, and the term lost its focus to a certain extent. An analysis of the definitions used by major organizations in the area of international development helps outline several dimensions of the concept of capacity building. These dimensions are: (a) focus on process; (b)different constellations of actors (often at micro and meso level: individuals, organizations, communities), (c) tasks, such as strengthening individual knowledge - at micro level - and skills and organizational abilities - at meso level - in different functional areas (for instance, human relations management, technological skills, project management skills, etc.), and (d) goals (improve performance, streamline service provision, strengthen accountability).

Capacity building efforts tend to be stratified depending on the actor's level (individual, organization, community), with the ultimate goal of contributing to the adequate service provision at societal level-macro level. The types of activities carried out depend, as well, on the actor's level and range from national-broad programs to local level individual and nonprofit-based activities providing responses to local community needs.

The concept of capacity is being "crucial to the success of the nations" (El-Taliawi and Van Der Wal 2019:246). Throughout the years, the concept took different forms in the public administration literature: state capacity, policy capacity, managerial capacity, and administrative capacity. Arguably, these dimensions can be split across the macro-meso dimension. State capacity can be considered as macro-level capacity and the policy, managerial and administrative capacities can be considered as dimensions to be investigated at meso (or organizational) level. A twodimensional conceptualization of the policy capacity focusing on skills and resources is proposed by Wu et al. (2015:166-167). They distinguish between the types of capacity (analytical, operational, and political) and the level where this capacity is analyzed (individual, organizational, and systemic) (Table 1).

Administrative capacity would require -according to this conceptualization- analytical and operational competences at individual and organizational level.

\section{Administrative Reform and Capacity Building}

Public sector reforms characterized the societal changes in the majority of countries in the last forty years. Each regional area had to deal with its own challenges, ranging from developing the state institutions, to (re)developing economic capacity, or developing social services (such as education and health). Within the different geographical areas in which capacity building activities took place, Central and Eastern Europe represents a particular case of reforms due to the trigger of the reforms, the collapse of the Soviet Union, and the transition from a bipolar to a multipolar world order. The reforms in Central and Eastern Europe took a particular direction because they were directed by the assumed goal of the countries to join European Union. In comparison to previous waves of European Union enlargement, for instance the Southern Enlargement where Greece, Spain, and Portugal joined the EU and where political institutions needed primary attention, in the Eastern Enlargement both democratic political institutions and a functional market economy had to be rebuilt (Milward et al. 2016). The pre-1989 institutional setting of the Central and Eastern European countries was characterized to large extent of state property, state centralization of the economy, and a very strong level of politicization of the public service. This combination of characteristics led to the situation that the Eastern European states had to fulfill a multiple challenge by reforming political and economic institutions, and by having to develop their administrative capacity to a level necessary to function in the EU. 
Capacity Building, Table 1 Policy capacity, skills and resources

\begin{tabular}{l|l|l|l}
\hline \multirow{2}{*}{$\begin{array}{l}\text { Levels of resources and } \\
\text { capabilities }\end{array}$} & Skills and competencies & \multicolumn{2}{l}{} \\
\cline { 2 - 4 } Individual & Analytical & Operational & Political \\
\hline Organizational & $\begin{array}{l}\text { Individual analytical } \\
\text { capacity }\end{array}$ & $\begin{array}{l}\text { Individual operational } \\
\text { capacity }\end{array}$ & $\begin{array}{l}\text { Individual political } \\
\text { capacity }\end{array}$ \\
\hline Systemic & $\begin{array}{l}\text { Organizational analytical } \\
\text { capacity }\end{array}$ & $\begin{array}{l}\text { Organizational operational } \\
\text { capacity }\end{array}$ & $\begin{array}{l}\text { Organizational political } \\
\text { capacity }\end{array}$ \\
\hline & $\begin{array}{l}\text { Systemic analytical } \\
\text { capacity }\end{array}$ & $\begin{array}{l}\text { Systemic operational } \\
\text { capacity }\end{array}$ & $\begin{array}{l}\text { Systemic political } \\
\text { capacity }\end{array}$ \\
\hline
\end{tabular}

Source: Table 1, Wu et al. (2015:167)

This capacity building challenge consisted of (a) conduct the process of state withdrawal from the economy and, (b) to reorganize the state on democratic bases. Consequently, the reform and capacity building efforts were initially focused on (political) institutions (multi-party system, free elections, Constitution). Particularly relevant for the purpose of this discussion is to observe that the neo-institutional approach was the primary approach used in designing and executing measures aimed towards capacity development. This focus resulted in stressing privatization and marketization of services and tasks provided before by the state. Moreover, less -if any- attention was dedicated to the classical institutional approach oriented towards the idea of "fit" between the old and new institutions and towards the influence of path dependencies in introducing social change (Gamal and Vaughan 2002).

Administrative capacity came later to attention of both academics studying European integration as well as of the policy makers developing the measures required during the accession process. It took time until it became clear that in order to implement policies, a certain level of capacity is needed. Decision makers and academics alike understood that focusing reforms only on political institutions, only on legislation adoption, or on setting the grounds for functioning market economies did not automatically lead to achieving the expected outcomes of political stability and economic prosperity. Understanding that administrative organizations in these countries simply did not have the necessary resources and capacity required for implementation led to the articulation of efforts necessary to develop the missing competences. Academics and policy makers alike had to be reminded that the existence of administration capacity should not be taken for granted.

The other interesting aspect of the challenge consists of the assumptions that (a) the policy change will be automatically implemented at organization level and (b) the change adopted in the central government will be automatically adopted and implemented as intended at local level. These assumptions were based on the European continental tradition of organizing public administration around legislation. Extensive reliance upon legislation as policy instrument lends itself easily to implementation inconsistency. This happens particularly when little attention is paid to ensuring the coordination and coherence among the content and the requirements of different pieces of legislation. Eventually, this leads to confusion among the executing authorities, and makes the implementation process very tortuous. Moreover, exclusive actions directed towards conducting change at a central level lead to the forming of "pockets of excellence" which, without sufficient levels of structural support, become isolated within the general body of the civil servants. Two consequences resulted from including these assumptions in the reforms: first, that the reform efforts were focused primarily at the central government level, and second, that only quite late in the accession process the decision-making attention was dedicated to the administrative capacity building.

Another characteristic of administrative capacity building resulted from the involvement of international actors such as World Bank, 
International Monetary Fund, the Organization for Economic Co-operation and Development (particularly through the initiative named Support for Improvement in Governance and Management) which provided support for capacity building actors. In addition, national development agencies and nonprofit organizations were active in the capacity building (Sobis and de Vries 2009). The relationship between the involvement of international actors - public and nonprofit - and the domestic political and societal actors tends to be rather delicate one, given the unequal power relationships developed between the two sets of actors (international donor and domestic actors) during such a capacity development program. A particular case represents the capacity building effort organized within the process launched by a number of the countries of Central and Eastern Europe with the aim to join the European Union. This process has been analyzed in the academic literature under the name of Europeanization of public administration. The asymmetric relationship between the candidate countries and the European Union (through the European Commission) has been analyzed in the academic literature from the perspective of conditionality (Schimmelfennig and Sedelmeier 2005).

In administrative terms, Europeanization process aimed to develop administrative systems able to function within EU's institutional framework. In assessing Public Administration Reforms, the term "administrative capacity" was initially operationalized through the Support for Improvement in Governance and Management initiative also known as SIGMA $(1998,1999)$ outlined in terms of achieving acceptable standards of reliability, predictability, accountability, transparency, efficiency, and effectiveness in policymaking (Cardona 2009). This implies that, during and after accession, Central and Eastern European countries reform efforts were focused towards building organizational and administrative capacity in order to develop institutions able to (a) act reliable and predictable according to the rule of law and the nondiscrimination principle; (b) answer to and be held accountable by other administrative, legislative, or juridical authorities; (c) function transparently and be open to external scrutiny; and (d) able to maintain an appropriate ratio between inputs, outputs, and outcomes, and act according to efficiency and effectiveness criteria of performance.

It needs to be specified as well that the dynamic process behind the development of administrative capacity is quite specific to the regional and country level. The particular characteristics of the political regime and the political-administrative relationships, the historical legacies, and the path dependencies have very strong consequences for the development of administrative capacity in a country or at regional level. Jreisat (2012) applies a number of dimensions for administrative capacity development for the case of the Arab States, such as integration of the different elements of the management systems, data and knowledge deficit, level of centralization in bureaucracy, transparency and accountability, and political capacity, emphasizes the idea of strategic thinking in order to develop administrative capacity. Jreisat (2012) pleads for a rethinking of administrative capacity as a crucial characteristic required for the governing of society (also Farazmand 2009: 1016, 1017), from the increasing rhythm of societal change, from globalization and the rapid change and impact of technology (Jreisat 2012:140).

\section{Capability}

The concept of capability is connected to the one of "capacity building." The concepts of "capacity" and "capability" are sometimes used interchangeably. There are, however, arguments to use them as synonyms, as well as arguments to separate them. On the one hand, it can be debatable to separate the two terms which address, in essence, the fundamental task of analyzing a given situation and, if considered necessary, take measures to address the difference between the current situation and the desired situation, such as through making deliberate efforts to acquire new skills. On the other hand, there are arguments to separate the two given their central focus: whereas capacity focuses on problem diagnosis, capability focuses on the acquiring of the particular skill (a person's ability to execute a particular 
task). Both imply the existence of separate skill sets, such as diagnosis skills required to identify that there is a problem for capacity, and the decision making required to undertake measures needed to address a perceived problematic situation in the capability. It is important to define the individual and context factors that make a difference for the necessity to act. Finally, capability has a clear normative component and seems to be focused on conceptualization, and capacity has a strong explanatory and empirical component.

Capability approach is an interdisciplinary theoretical framework developed in order to define and evaluate poverty, inequality, or well-being, at individual and societal level, in order to support policy design and policy development aimed to bring change in society (Robeyns 2005:94). Capability approach has a normative component and focuses on what people are in practice able to do. This approach goes beyond strict utilitarian components of a "package of skills" that allow people to perform certain tasks and it is highly contextualized to the situation where the person whose abilities are being developed does function. The concept of capability allows to deepen the analysis and take into account both the specific situation and context in which the skill development takes place, and the individual freedom to choose the ways to pursue one's life according to the desired goals. The theoretical grounds of the capability approach lay with the work of Amartya Sen (1985) and Martha Nussbaum. Whereas Sen's argument is developed more towards policy formulation towards supporting individuals learn the skills they need to achieve freedom and the type of life they aim to pursue, Nussbaum's approach focuses more on developing a partial theory of justice.

In the capability approach, the distinction between means and ends is important, as the latter have an intrinsic importance: well-being, justice, and development framed in terms of people's capability to function (Robeyns 2005:95). Additionally, this distinction allows to differentiate between what is achieved and what is effectively possible, and therefore accounts for the conditions of the actual implementation and application of the learned skills. This difference has an important consequence for the policy evaluation, allowing to take into account the context and the extent to which the acquiring of a particular skills does contribute to the achieving a fulfilling life as imagined by the individual. This is particularly important for the policies whose objective is designed have an impact for the development of individual abilities to pursue individually defined goals. This extends the possibilities for evaluation also, for instance, to address the latent mechanisms that contribute to the development of social inequality present also in developed and well-off societies. Martha Nussbaum (2004) develops further the capability approach by arguing that the governments should sanction a list of "central human capabilities" and include them within the fundamental rights which should stay at the grounding of the development of each citizen. Her approach is on the legal-moral-normative dimension, and provides a universalistic perspective on human development.

\section{Conclusion}

The discussion regarding capacity building requires an increased attention, both by academics as well as by policy makers. The current societal challenges faced by governments needing to respond to global challenges such as pandemics, change in volume and direction of human migration flows, climate change, or technologically induced situations such as cyber-crime and cyber terrorism, require new types of responses as well as new mechanisms of coordination for governments and across governments and societal actors such as nonprofit organizations and private sector. These types of responses require, on their turn, a different mindset of governing societies. First, the understanding that, even though governments are ultimately responsible to execute their core tasks on providing public services security and safety, they cannot do it alone. Cooperation with societal actors is essential, particularly in cases of emergency response. Citizens demand more and more involvement in the formulation and, at times, even in the execution of policies. Second, that these new challenges require new sets of skills and 
resources, both analytical and operational, at individual and organizational level. These rapid changes require a continuously evolving mindset, focused on learning to deal with constant change, which makes administrative capacity a dynamic characteristic of governments both at organizational and at the individual level.

The crucial question is how to find the suitable balance between the constant change and the necessary level of equilibrium required for a smooth operation of governmental organizations within a turbulent environment. One possible answer could be provided in the re-assessment of the lessons learned from the administrative capacity building literature in developing countries and in transition countries. In the recent decennia, these countries have conducted major political and administrative reforms, and executed them with variable degree of success. It is important to realize that these reforms, major societal changes, were achieved in a constantly changing political, economic, and technological environment. The literature was primarily focused on analyzing mechanisms behind failures in policy development, implementation, or goal achievement with arguably more limited interest on understanding mechanisms behind success. It is also relevant to bear in mind that success was usually defined in terms and standards characteristics to developed states with relatively extended track records of functioning administrations. With the possible exceptions in policy areas such as water management or natural disaster mitigation, limited attention was given towards understanding mechanisms of transfer of knowledge from the developing countries to the developed countries - with all the caveats needed by the definitions of the concept of development.

The countries which have already dealt with a high level of instability and still managed to develop adequate governmental responses to societal challenges can offer insights on the parameters and ways to deal with developing administrative capacity so highly needed to address current societal challenges. Because, in the words of Farazmand (2009: 1016) "Nothing gets done without administrative capacity."

\section{Cross-References}

\author{
- Administrative Development \\ - Administrative Reforms \\ - Capability \\ > Organizational Learning
}

\section{References}

Cardona F (2009) Attractiveness of the public service: a matter of Good Public Governance, SIGMA document. Available online at: http://www.oecd.org/dataoecd/32/ 51/44110902.pdf. Last access 28 Feb 2020

El-Taliawi OG, Van Der Wal Z (2019) Developing administrative capacity: an agenda for research and practice. Policy Design Pract 1:1-15

Farazmand A (2009) Building administrative capacity for the age of rapid globalization. Public Adm Rev 69(6): 1007-1020

Gamal I, Vaughan G (2002) Bye-bye central planning, hello market hiccups: institutional transition in Romania. Camb J Econ 26:105-118

Jreisat JE (2012) Rethinking administrative capacity development: the Arab States. Public Organiz Rev 12:139155. https://doi.org/10.1007/s11115-011-0164-5

Milward B, Jensen L, Roberts A, Dussauge-Laguna MI, Junjan V, Torenvlied R, Boin A, Colebatch HK, Kettl D, Durant R (2016) Is public management neglecting the state? Governance. https://doi.org/ 10.1111/gove. 12201

Nussbaum M (2004) Beyond the social contract: capabilities and global justice. Oxf Dev Stud 32(1):3-18

Pollitt C, Bouckaert G (2011) Public management reform. A comparative analysis: new public management, governance, and the neo-Weberian state. Oxford University Press

Robeyns I (2005) Capability approach: a theoretical survey. J Hum Dev 6(1):93-117

Schimmelfennig F, Sedelmeier U (2005) The Europeanization of central and Eastern Europe. Cornell University Press

Sen A (1985) Well-being, agency and freedom. J Philos LXXXII(4):169-221

SIGMA-OECD (1998) Preparing public administrations for the European administrative space. SIGMA Papers 23. Available online at: http://www.oecd.org/dataoecd/ 20/56/36953447.pdf. Last access 28 Feb 2020

SIGMA-OECD (1999) European principles for public administration, SIGMA Papers 27. Available online at: http://www.oecd.org/dataoecd/26/30/36972467. pdf. Last access 28 Feb 2020

Sobis I, de Vries MS (2009) The story behind Western advice to Central Europe during its transition period. NISPAcee Press, Bratislava

Wu X, Ramesh M, Howlett M (2015) Policy capacity: a conceptual framework for understanding policy competences and capabilities. Polic Soc 34:3-4 